\title{
Nasalization as a Repair for Voiced Obstruent Codas in Noon John Merrill ${ }^{1}$
}

LSA Annual Meeting, Portland, January 8-11, 2015

The Senegalese language Noon exhibits a pattern by which the voiced stop phonemes $/ \mathrm{b}$, $\mathrm{d}, \mathrm{J}, \mathrm{g} /$ surface as nasals $[\mathrm{m}, \mathrm{n} \mathrm{n}, \mathrm{n}]$ in coda position, undergoing complete neutralization with $/ \mathrm{m}$, $\mathrm{n}, \mathrm{n}, \mathrm{n} /$. This allophonic alternation can be seen as a repair to the cross-linguistic constraint against voiced obstruents in coda position. However, the only otherwise attested repair to this marked structure is devoicing. Why should devoicing be so overwhelmingly preferred to other logical alternatives such as nasalization or gliding? Steriade (2008) answers this question with reference to her P-Map hypothesis, arguing that $a[b \sim p]$ alternation is preferred because the perceptual distance between these sounds is less in this environment than between [b] and [m]; in essence, the synchronic system prefers a repair that changes a sound as little as possible, as determined by perceptual distinctness. The Noon facts are a clear counter-example to this prediction, and challenge any answer to the above question which requires synchronic systems to prefer the most "phonetically natural" repair.

\section{Coda devoicing and the Too Many Solutions problem}

Voiced obstruent codas are cross-linguistically marked, and are often avoided by active devoicing alternations, e.g. /tab/ $\rightarrow$ [tap] (see Myers 2012 for an overview). But why should devoicing be the only repair for voiced obstruent codas? Steriade (2008) notes that there are a number of other hypothetical repairs that would avoid the marked structure just as effectively.

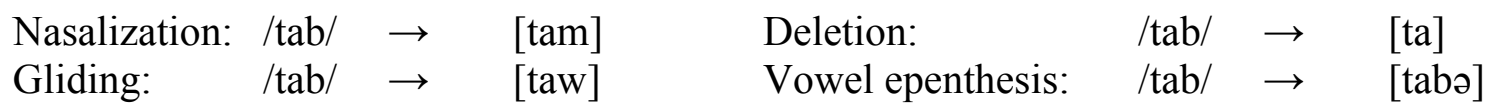

In Optimality Theory, a simple a simple re-ranking of faithfulness constraints would be enough to get these other repairs; and yet it is often noted that the only attested repair is devoicing (Steriade 2008, Blumenfeld 2006, Hermans and Ostendorp 2007). This problem is known in the literature as the "Too Many Solutions" problem.

To solve the Too Many Solutions problem, Steriade (2008) proposes the P-map, a principled way of ranking the constraints of a language such that repairs change the UR in the most perceptually minimal way. The P-map predicts that because the voicing contrast is less perceptible in coda position than a nasality contrast, IDENT[nas]/CODA will outrank IDENT[voi]/CODA. In effect, for a UR/tab/, [tap] is perceptually closer to [tab] than any other conceivable repair, and is thus always preferred. As a consequence, Steriade notes that "...one does not encounter sound systems in which all the final voiced stops, and only they, turn to nasals..." (2008: 153). She illustrates what such a hypothetical system would look like:

$\begin{array}{llllll}\text { before vowel: tib-a tud-a tag-a } & \text { top-a tat-a tek-a } \\ \text { word final: tim tun tan } & \text { top tat tek }\end{array}$

Noon is thus noteworthy in that it exhibits exactly this pattern:

$\begin{array}{lll}\text { imperative: } & \text { [yab-a][bíd-a] [lag-a] } & \text { [tap-a] [hot-a] [6ak-a] } \\ \text { bare verb: } & \text { [yam] [bín] [lap] } & \text { [tap] [hot] [6ak] } \\ & \text { 'land' 'write' 'close' } & \text { 'pound 'see' }\end{array}$

\footnotetext{
${ }^{1}$ Thanks to Nico Baier, Christine Diop, and Larry Hyman. Author: John Merrill, U.C. Berkeley (jtmm@berkeley.edu)
} 


\section{Coda Nasalization (CN) in Northern Noon}

Noon is a member of the Cangin language family of Senegal, consisting of five rather closely-related languages spoken in and around the city of Thiès. Three distinct dialects of Noon can be identified: the Thiès dialect spoken in the city (Lopis 1981), the Padee dialect spoken in the eastern villages (Soukka 2000), and the Saawii dialect spoken in the northern villages, on which I conducted fieldwork with Christine Diop, a speaker from the village of Lalane. These last two dialects behave identically with respect to $\mathrm{CN}$, and can be referred to together as "Northern Noon." The consonant inventory of Northen Noon is given below:

\begin{tabular}{|c|c|c|c|c|c|}
\hline & labial & coronal & palatal & velar & glottal \\
\hline vl. stop & $\mathrm{p}$ & $\mathrm{t}$ & $\mathrm{c}$ & $\mathrm{k}$ & $?$ \\
\hline vd. stop & $\mathrm{b}$ & $\mathrm{d}$ & $\mathrm{j}[\mathrm{f}]$ & $\mathrm{g}$ & \\
\hline nasal & $\mathrm{m}$ & $\mathrm{n}$ & $\tilde{\mathrm{n}}[\mathrm{n}]$ & $\eta$ & \\
\hline prenas. stop & $\mathrm{mb}$ & nd & nj [nJ] & ng & \\
\hline implosive stop & 6 & $d$ & $y$ & & \\
\hline vl. continuant & $\mathrm{f}$ & \multicolumn{2}{|c|}{$S$} & \multicolumn{2}{|c|}{$\mathrm{h}$} \\
\hline vd. continuant & $\mathrm{W}$ & $(\mathrm{r})$ & $\mathrm{y}$ & & \\
\hline
\end{tabular}

Note that the only voiced obstruents are stops. Tautomorphemic prenasalized stops are rare, and found only in borrowings. Vowels are irrelevant to this discussion, but is should be noted that $<\ddot{e}$, é, í, ó, ú> represent [+ATR] vowels in the Cangin languages.

Some further examples of the phenomenon of coda nasalization are given below.

\begin{tabular}{|c|c|c|c|c|c|c|}
\hline bare $\mathrm{v}$ & erb & punctual & & past -ee & & \\
\hline kúb & [kúm] & kúb-ba & [kúmba] & kúb-ee & [kúbee] & 'macerate' \\
\hline & [kon] & kod-da & [konda] & kod-ee & [kodee] & ‘cry' \\
\hline & [pañ] & paj-ja & [pañja] & paj-ee & [pajee] & 'marry' \\
\hline awaag & [awaan] & awaag-ga & [awaanga] & awaag-ee & [awaagee] & 'open mouth' \\
\hline are $n$ & oun & pl. proxin & ef. $-c-i i$ & proximal c & & \\
\hline íib & [yíim] & ýib-c-ii & [yíimcii] & yíib-ii & [yíibii] & 'chin' \\
\hline had & [nan] & nad-c-ii & [nancii] & nad-ii & [nadii] & ‘spider' \\
\hline bíig & [bíin & bíig-c-ii & [bíincii] & bíig-ii & [bíigii] & ‘back’' \\
\hline
\end{tabular}

These alternations are purely allophonic; that is, they are exceptionless, and completely predictable from the phonological environment.

Voiced stop-final roots contrast with nasal-final roots, which show no allophony.

$\begin{array}{lllll}\text { bare verb } & \text { perfect }- \text { in } & & \text { bare verb } & \text { perfect -in } \\ \text { ab [am] } & \text { ab-in [abin] } & \text { 'hold' } & \text { ñam [ñam] } & \text { ñam-in [ñamin] 'eat' } \\ \text { tab [tam] } & \text { tab-in [tabin] 'be forbidden' } & \text { tam [tam] } & \text { tam-in [tamin] 'be hot' } \\ \text { mad [man] } & \text { mad-in [madin] 'resemble' } & \text { an [an] } & \text { an-in [anin] 'drink' } \\ \text { dag [day] } & \text { dag-in [dagin] 'be taut' } & \text { dan [dan] } & \text { day-in [danin] 'be viscous' }\end{array}$

Voiceless stop codas are common, and show no alternations. There is no general dispreference for stop codas - only voiced stop codas. There is no reason why coda devoicing would not be an available repair. 


\section{The Cangin languages and the historical origin of Coda Nasalization}

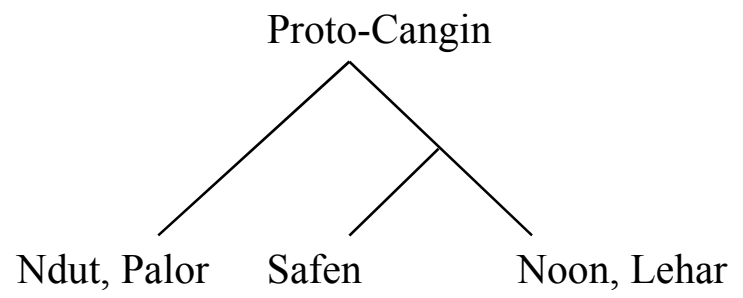

Ndut: Morgan (1996)

Palor: D'Alton (1983)

Safen: Mbodj (1983)

Lehar: Dieye (2010)

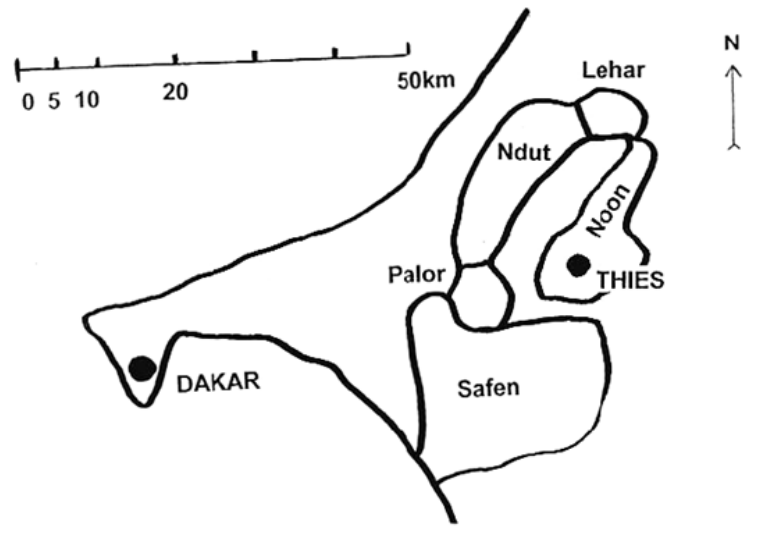

(Soukka 2000: 16)

Ndut and Palor show essentially the same alternations as Northern Noon on the surface.

Ndut, Palor

bare verb

som

man

pay

negative -ay
sob-ay
mad-ay
pag-ay

'pound'

'resemble'

'cook'
$=\mathrm{N}$. Noon

/soob/

$/ \mathrm{mad} /$

/pag/ 'do'

Neither D'Alton or Morgan explictly refer to these patterns as allophonic. In Palor there are apparently non-alternating coda voiced stops, but Morgan notes that Ndut has none- Ndut could thus be analyzed in the same way as Northern Noon. The facts in Lehar are somewhat unclear, but the facts seem to be the same as in Northern Noon.

The voiced stop phonemes of Northern Noon correspond to prenasalized stops in Thiès Noon, and these also have pure-nasal coda allophones.

\begin{tabular}{|c|c|c|c|c|c|}
\hline $\begin{array}{l}\text { N. Noon } \\
\text { dood } \\
\text { baal } \\
\text { dagal }\end{array}$ & $\begin{array}{l}\text { Thiès Noon } \\
\text { ndood } \\
\text { mbaal } \\
\text { ndangal }\end{array}$ & $\begin{array}{l}\text { ‘stick' } \\
\text { ‘sheep' } \\
\text { ‘scorpion' }\end{array}$ & $\begin{array}{l}\text { N. Noon } \\
{[\text { am } \sim \text { ab-a }]} \\
{[\text { man } \sim \text { mad-a }]} \\
{[\text { pan } \sim \text { pag-a }]}\end{array}$ & $\begin{array}{l}\text { Thiès Noon } \\
{[\text { am } \sim \text { amb-a }]} \\
{[\text { man } \sim \text { mand-a }]} \\
{[\text { pay } \sim \text { pang-a }]}\end{array}$ & $\begin{array}{l}\text { 'hold' } \\
\text { 'resemble' } \\
\text { 'do' }\end{array}$ \\
\hline
\end{tabular}

In Safen, Northern Noon /b, d, j, g/ correspond to [mb, nd, nj, ng] in all positions.

\begin{tabular}{llllll} 
Safen & N. Noon & & Safen & \multicolumn{2}{c}{ N. Noon } \\
njol & jol & 'cricket' & kung & kúg & [kún] 'fold/bend' \\
paangi & péegí & 'grass' & amb & ab & {$[\mathrm{am}]$ 'hold' } \\
pambi & pabi & 'chicken' & pang & pag & [pay] 'work/do' \\
ngul & gúl & 'pierce' & rang & lag & [lay] 'close'
\end{tabular}

These correspondences must be reconstructed as prenasalized stops (External evidence: ProtoCangin *ding = Sereer ding 'fence in,' PC *mbaal = Sereer mbaal 'sheep').

$\begin{array}{lllllll}\text { Proto-Cangin } & \text { Ndut\&Palor } & \text { Safen } & \text { Lehar } & \text { N. Noon } & \text { Thiès Noon } & \\ \text { *hang } & \text { hay } \sim \text { hag- } & \text { ang } & \text { ay } \sim \text { ag- } & \text { ay } \sim \text { ag- } & \text { ay } \sim \text { ang- } & \text { 'be wide' } \\ \text { *hamb } & \text { ham } \sim \text { hab- } & \text { amb } & \text { am } \sim \text { ab- } & \text { am } \sim \text { amb- } & & \text { 'hold' } \\ \text { *pang } & \text { pay } \sim \text { pag- } & \text { pang } & \text { pay } \sim \text { pag- } & \text { pay } \sim \text { pang- } & \text { 'do/cook' } \\ \text { *yoond } & \text { yoon } \sim \text { yood- } & & \text { yoon } \sim \text { yood- } & \text { yoon } \sim \text { yood- yoon } \sim \text { yoond- 'learn' }\end{array}$


While Safen retains the original prenasalized stops in all positions, the other languages all underwent a sound change *ND $>\mathrm{N}$ in coda position. All languages except Safen and Thiès Noon subsequently underwent a denasalization change *ND $>\mathrm{D}$ in onset position. Crucially, Proto-Cangin had no plain voiced stops, and thus all instances of voiced stops in Northern Noon came from earlier prenasalized stops.

We can now compare the historical origins of Final Devoicing (FD) and CN (at least as it arose in Noon) to explain one is so frequent and the other is so rare. Firstly, the precursor to FD is simply to have voiced stops in coda position. For $\mathrm{CN}$, the language must have prenasalized stops in all positions, and no plain voiced stops - a much more typologically rare situation. From these starting points, FD requires only one common sound change: devoicing of coda obstruents. For $\mathrm{CN}$, two sound changes must operate: $\mathrm{ND}>\mathrm{N}$ in coda position, and ND $>\mathrm{D}$ in onset position. The second of these changes is not particularly common cross-linguistically.

\section{Conclusions}

If we accept that sound change is phonetically natural, 'unnatural' alternations cannot arise from a single sound change. Broadly, the more perceptual distance in an alternation, the more sound changes must have occurred. The P-map is generally successful because it accounts for those alternations which result from a single sound change. But series of sound changes do sometimes result in unnatural alternations which have no synchronic phonetic motivation (Stausland Johnsen 2012). The test for the P-map is then as follows: if such an unnatural alternation effectively repairs a marked structure, will a language tolerate it despite the availability of a more 'natural' repair? Noon suggests that it will. Any mechanism which limits the possible constraint rankings of a language must then allow for some degree of arbitrariness, and not rely entirely on perceived similarity effects.

\section{References}

Blumenfeld, Lev. 2006. Constraints on phonological interactions. Stanford University: Doctoral thesis.

D’Alton, Paula. 1983. Esquisse phonologique et morphologique du Palor, langue Cangin (Sénégal). Université de la Sorbonne Nouvelle: Doctoral thesis.

Dieye, El Hadji. 2010. Description d'une langue Cangin du Sénégal: Le Laalaa. Dakar: Université Cheikh Anta Diop de Dakar.

Hermans, Ben and Marc van Oostendorp. 2007. "Solving the Too-many-solutions-problem." Talk presented at the Meertens Institute, June 4, 2007.

Lopis, Jeanne. 1981. Phonologie et morphologie nominale du noon, parler de Nguente. Université de la Sorbonne Nouvelle: Doctoral thesis.

Mbodj, Cherif. 1983. Recherche sur la phonologie et la morphologie de la langue saafi: le parler de Boukhou, Sénégal. Université de Nice: Doctoral thesis.

Morgan, Daniel Ray. 1996. Overview of Grammatical Structures of Ndut. UT Arlington: Master's thesis.

Myers, Scott. 2012. "Final devoicing: Production and perception studies.” In T. Borowsky, S. Kawahara, T. Shinya, and M. Sugahara (eds.) Prosody Matters: Essays in Honor of Elisabeth Selkirk, (pp. 151-179). London: Equinox Press, London.

Soukka, Maria. 2000. A Descriptive Grammar of Noon. Lincom Europa.

Stausland Johnsen, Sverre. 2012. “A diachronic account of phonological unnaturalness.” Phonology 29, (pp. 505531).

Steriade, Donca. 2008. “The phonology of perceptibility effects.” In Hanson, K. and Inkelas, S. (eds.) The nature of the word, (pp. 151-179). Cambridge: MIT Press. 